\title{
Lise Öğrencilerinin Matematik Başarısı, Kaygısı ve Öğretim Teknolojilerine Yönelik Tutumları Üzerine: GeoGebra Dinamik Yazılımı
}

\author{
High School Students' Mathematics Achievement, Anxiety and \\ Attitudes Towards Instructional Technologies: GeoGebra Dynamic \\ Software
}

\author{
Gamze TÜZER ÜNSAL ${ }^{1}$, Cenk AKAY²
}

Öz

Bu araştırmanın amacı, matematik derslerinde GeoGebra dinamik yazılımının kullanımının,10.sınıf öğrencilerinin akademik başarılarını, matematik kaygılarını ve öğretim teknolojilerinin kullanımına yönelik tutumlarını nasıl etkilediğini ortaya koymaktır. Araştırmada, deneysel yöntem çeşitlerinden olan yarı-deneysel desen kullanılmışıı. Araştırma grubunu 2016-2017 eğitim-öğretim yılında, bir devlet lisesinde öğrenim gören 10. sınıf öğrencileri oluşturmuştur. Kontrol grubunda 30, deney grubunda ise 34 olmak üzere araştırmaya toplam 64 öğrenci katılmışır. Araştırmada nicel ve nitel veri olmak üzere iki tür veri toplanmışır. Nicel veri toplama araçlarından elde edilen veriler SPSS programı kullanılarak, nitel veri toplama araçlarından elde edilen veriler ise içerik analizi yöntemi kullanılarak analiz edilmiştir. Araştırma sonucunda, deney grubunda matematik kaygı ölçeği ve matematik başarı testinden alınan ön-test ve son-test puanları arasında son test lehine anlamlı fark bulunmuştur. Deney grubu ve kontrol grubu karşılaştııılı̆̆ında ise, matematik başarı testinden alınan erişi puanları açısından, deney grubu lehine anlamlı bir fark bulunmuştur. Ayrıca, deney grubunda bulunan öğrenciler genelde, derste GeoGebra dinamik yazılımının kullanılmasının olumlu yönleri olduğunu; eğlenceli, görsel, pratik, aktif, teknolojik bir araç olma, etkili öğrenme ve öğrenmede hız sağlama özelliklerini sevdiklerini ve bu yazılımı başka derslerde de kullanmak istediklerini belirtmişlerdir

Anahtar Kelimeler: geogebra dinamik yazılımı, matematik kaygısı, öğretim teknolojilerine yönelik tutum, matematik başarısı

\section{Abstract}

The aim of this study is to demonstrate how the use of GeoGebra dynamic software in mathematics courses influences the academic achievement of 10th grade students, their math anxiety and their attitudes towards the use of instructional technologies. In the study, quasi-experimental design is used. The research group consisted of 10th grade students in a public high school in the academic year 2016-2017. A total of 64 students participated in the study, 30 in the control group and 34 in the experimental group. In the research, two types of data were collected: quantitative and qualitative data. The data obtained from the quantitative data collection tools were analyzed by using SPSS program and the data obtained from qualitative data collection tools were analyzed by using content analysis method. At the end of the study, a significant difference was found between the pre-test and post-test scores of the mathematic anxiety scale and mathematics achievement test in the experimental group. When the experimental group and the control group were compared, a significant difference was found in favor of the experimental group in terms of achievement scores obtained from the mathematics achievement test. In addition, the students in the experimental group generally stated that there are positive aspects of using GeoGebra dynamic software in the course and that they pointed that the software provided visual, practical, active, learning. They also stated that they would like to use the software in other courses.

Keywords: geogebra dynamic software, math anxiety, attitude towards instructional technology, mathematics achievement

\footnotetext{
${ }^{1}$ Mersin Üniversitesi, Eğitim Fakültesi, Eğitim Programları ve Öğretim ABD, Mersin, Türkiye

${ }^{2}$ Mersin Üniversitesi, Eğitim Fakültesi, Eğitim Programları ve Öğretim ABD, Mersin, Türkiye

Atıf / Citation: Tüzer Ünsal, G. ve Akay, C. (2019). Lise Öğrencilerinin Matematik Başarısı, Kaygısı ve Öğretim Teknolojilerine Yönelik Tutumları Üzerine: GeoGebra Dinamik Yazılım. Kastamonu Education Journal, 28(1), 234-252. doi:10.24106/kefdergi.3538
} 


\section{Extended Abstract}

Introduction: Due to its nature, mathematics is one of the problems that students have difficulty in learning and often have problems with. Among the other causes of this problem in mathematics lessons can be shown the components of the learning process. One of these components is the teaching methods used in mathematics teaching. Traditional teaching methods used in teaching mathematics make the lesson boring, incomprehensible and difficult because it does not activate the student in the course. For this reason, in today's mathematics courses, the instructional technologies that enable the active participation of students are increasing rapidly. Therefore, teaching methods and techniques should be used to reduce the math anxiety of the students. GeoGebra dynamic software is also an instructional technology in accordance with these teaching methods. The aim of this study is to determine how the use of GeoGebra dynamic software in mathematics lessons affects the academic achievement of 10th grade students and their attitudes towards the use of mathematics concerns and the use of instructional technologies.

Method: In this study, quasi-experimental design is used. The research group consisted of the students of two classes with the closest equivalence from the 10th grade students attending a state high school. While the control group was consisted of 30 students, the experimental group was consisted of 34 students. Mathematics academic achievment test, math anxiety scale, attitude scale towards instructional technologies and an open-ended questions form were used as data collection tools. In the study, quantitative data were analyzed by using t test in related samples and two-way ANOVA at repeated measures after the analysis of normality distributions. Qualitative data were analyzed by content analysis. The experimental process lasted 6 weeks.

Findings: According to the paired-samples t-test analysis, a significant difference between the pre-test and the post-test scores was observed at the math success, math anxiety and instructional technologies attitudes at the control group students. For the second research question, According to the paired-samples t-test analysis, while there was a significant difference between the pre-test and the post-test scores observed at the math success and math anxiety at the experimental group students, a significant difference was not found at their instructional Technologies attitudes. Two way ANOVA at repeated measures analysis was used to analyze the third research question. According to the analysis results, when the access scores of the two groups compared; while there was no significant difference at math anxiety, the significant difference was observed at math success (in favor of experimental group) and instructional technologies attitudes (in favor of control group ). When the codes of the experimental group students' opinions about the GeoGebra dynamic software were examined, it was stated that the use of the GeoGebra dynamic software in the lesson made mathematics fun, that it attracted attention, effective learning, ease of learning, permanent learning, active learning, visuality, learning speed.

\section{Suggestions}

- The GeoGebra dynamic softwares should be delivered to the students in a comprehensive, programmatic manner, and students should be allowed to review the software before it is used.

- GeoGebra dynamic softwares should be installed on interactive whiteboards in schools and students should be introduced to the program at basic level.

- In-service training programs should be organized to inform and raise awareness of the use and benefits of teachers, GeoGebra and similar dynamic softwares.

- GeoGebra dynamic softwares should be installed on students' mobile phones so that the students can follow the GeoGebra Institute in Ankara online and be in an interactive learning environment.

- Activities supported by GeoGebra and similar dynamic softwares in secondary mathematics textbooks should be increased.

- In order to use Geogebra and similar dynamic softwares in different courses, necessary modifications should be made in the curriculum.

Suggestions for Researchers

- The duration of the research can be extended to make more detailed examinations on the effect of the GeoGebra dynamic software on the affective characteristics of students such as attitude and anxiety.

- Affective characteristics such as resistance, buoyancy and similar issues can be studied.

- The opinions and suggestions of the in-service math teachers towards the use of GeoGebra dynamic software can be researched.

Different dynamic softwares developed for math instruction can be compared in quasi-experimental researches. 


\section{Giriş}

Matematik doğası gereği öğrencilerin öğrenmekte zorlandığı ve çoğu zaman sorun yaşadığı derslerden biri olmaktadır. Yenilmez ve Dereli (2009), genel olarak, soyut kavramların kazanılmasının zorluğunu matematiğin öğrencilere zor gelmesinin sebebi olarak gösterirken; Boz (2008) ise kavramların ve kuralların değişik yönlerinin birbirinden bağımsız şekilde algılanması durumunda matematik çalışırken yaşanan zorluğa işaret etmiştir. Dursun ve Dede (2004) yaptıkları araştırmada matematik müfredatına atıfta bulunarak matematiğin öğretiminde kullanılan geleneksel öğretim yöntemlerinin de soyut bir dil içeren matematiğin anlaşılmasını zorlaştırdığını vurgulamıştır. Bu açıklamalardan yola çıkarak matematik öğretiminde kullanılan geleneksel öğretim yöntemlerinin, öğrenciyi derste aktifleştirmediği için dersi sıkıcı, anlaşılmaz ve zor hale getirdiği söylenebilir. Günümüzde matematik derslerinde öğrencilerin ilgisini çekmek, dersi eğlenceli hale getirmek ve öğretim programında belirtilen kazanımlara ulaşmalarını kolaylaştırmak için öğretim teknolojileri destekli öğretim yöntemleri kullanılabilir. Alakoç’a (2003) göre, artık öğretmenlerin teknolojik araçları, öğrencilerin ilgilerini artırmak ve matematiği anlamalarını kolaylaştırmak için kullanmaları gerektiği de kabul edilmektedir. Matematik ve geometri derslerinde, öğrencilere görsel temsil ve somutlaştırma sağlayarak modelleme yapmaya olanak tanıyan ve problem çözme becerilerini geliştiren farklı öğretim teknolojileri bulunmaktadır (Karaaslan, Boz ve Yıldırım, 2013). Matematik derslerinde kullanılabilecek çeşitli yazılımlar; çıkarsama yapma, tahmin etme, model kurma ve problem çözme sürecini geliştirmektedir (Milli Eğitim Bakanlığı [MEB], 2018). Bu yazılımlar içinde, dinamik matematik yazııımları, aynı anda sayısal, cebirsel ve grafiksel gösterim sunduğu için öğrencilere daha güçlü öğrenme ortamları sağlar (Kaleli Yılmaz, Ertem ve Güven, 2010). Cabri Geometri, Geometer's Sketchpad ve GeoGebra gibi geometri ve matematik öğretimi için geliştirilmiş farklı dinamik yazılımlar bulunmaktadır (Moss, 2000). Bu nedenle dinamik yazılımların matematik öğretiminde kullanılmasılyla ilgili araştırmalara rastlanılmaktadır. Yapılan araştırmalar incelendiğinde belirtilen yazılımların, anlamlı öğrenmeyi desteklediği (Abar ve Barbosa 2011); öğrencileri aktif kıldığı ve dinamik sanal bir çevre oluşturduğu (Dijanic, 2011); öğretmenlerin sahip olduğu geometri bilgisini geliştirmeye fırsat tanıdığı (Lopez, 2011); öğrencileri motive ettiği ve matematiksel somutlamaya destek olduğu (Choi, 2010); çeşitli görselleştirme imkanları ile öğrencilerin geometrik kavramları öğrenmelerine katkıda bulunduğu ve kavramlar arası ilişkileri daha kolay kurmalarını sağladığı (Saha, Ayup ve Tarmizi, 2010); öğrencilerin anlamasına ve bilgisine olumlu etkide bulunduğu (Dikovic, 2009) sonuçlarına ulaşılmıştır. Dinamik matematik yazılımları arasında ise GeoGebra yazııımı, sağladığı olanaklar, ücretsiz olması ve kolay kullanımı ile diğer yazılımlardan ayrılır. Bu bağlamda GeoGebra matematik derslerini soyutluktan kurtararak öğrencilerin bilgilerini kendilerinin yapılandırmasına izin verdiği düşünülebilir. Literatür incelendiğinde GeoGebra yazılımının matematik öğretiminde kullanılmasıyla ilgili yurt içinde ve yurt dışında çalışmalar yapıldığı görülmektedir. Yazııımın, öğrenciler açısından matematik akademik başarıları ile kavramsal öğrenmelerine olan etkisi (Öz, 2015; Thambi ve Kwan Eu, 2013; Kepceoğlu, 2010), geometri özyeterliliklerine olan etkisi (Balcı Şeker, 2014) ile öğrencilerin bilişsel, işbirlikli ve yapılandırmacı öğrenme süreçleri üzerindeki desteği (Chrysanthou, 2008) incelenmiştir. Öğretmenler açısından ise yazılımın öğretmenlerin matematik öğretme süreçlerine (Majerek, 2014; Žilinskienė, 2014) ve mesleki gelişimlerine olan katkısı (Escuder ve Furner, 2011) araştırma konuları olmuştur. Öğrencilerin matematiği zor olarak görmelerini ve düşünmelerini engellemek veya bu süreci tersine çevirmek için bu tür yazılımların kullanılmasının sürece olumlu yönde etki edeceği düşünülebilir. Ancak bu süreçte öğrencilerin matematik öğrenmelerinde araştırmacıların üzerinde durduğu bir başka unsur da kaygıdır (Zengin, 2017; Özçakır ve Sümen, 2013). Yenilmez ve Özbey'e (2006) göre, matematiğe olan kaygı, korku ve ondan çekinme davranışlarını kapsar ayrıca ilerlemesi halinde o kimsenin kaygılandığı durumu başaramayacağı inancına kapılmasına yol açmaktadır. Ayrıca yapılan araştırmalarda matematik eğitiminde kullanılan yöntem ve teknikler, matematik kaygısının en önemli sebeplerinden biri olarak bulunmuştur (Trujillo ve Hadfield, 1999; Woodard, 2004). Bu nedenle öğretim ortamları düzenlenirken öğrencilerin matematik kaygılarını azaltacak ve onları aktif kılacak öğretim yöntem ve teknikleri kullanılmalıdır. GeoGebra dinamik yazılımı da bu öğretim yöntemlerine uygun bir öğretim teknolojisidir. Sarıtaş'a (2013) göre bu teknoloji öğrenciyi aktif hale getiren öğrenci merkezli öğrenme ortamlarında, öğrencilerin ilgi ve dikkatlerinin derse çekilmesi ve matematiğe yönelik olumlu tutumlarının geliştirilmesi ile öğretim teknolojilerinin daha etkili kullanılmasını sağlayabilir. GeoGebra yazılımı öğrencilere zengin deneyimler sağlamakta, araştırma, keşfetme ortamları sunmaktadır. Verilen bilgiler ışığında, bu araştırmanın amacı, matematik derslerinde GeoGebra dinamik yazılımının kullanımının,10.sınıf öğrencilerinin akademik başarılarıı, matematik kaygılarını ve öğretim teknolojilerinin kullanımına yönelik tutumlarını nasıl etkilediğini ortaya koymaktır. GeoGebra yazılımının kullanımında matematik dersi 10. sınıf programında yer alan "ikinci Dereceden Fonksiyonlar" alt öğrenme alanı örnek olarak seçilmiştir. Araştırmanın uygulamasında örnek olarak 10. sınıf matematik dersi ikinci dereceden fonksiyonlar alt öğrenme alanının seçilmesinin nedeni, bu konunun öğretiminde grafik gibi görsel materyallerin kullanımına ihtiyaç duyulmasıdır. Ayrıca bu konunun 
işlem yükünün fazla olması nedeniyle öğrencilerin kazanımlara odaklanması zorlaşmaktadır. GeoGebra dinamik yazılımı ile öğrencilerin grafiksel gösterimden faydalanıp kazanımlara rahatça ulaşabileceği düşünülmektedir. Belirtildiği üzere, bu araştırmanın önemli değişkenlerinden biri de matematik kaygısıdır. Literatüre bakıldığında GeoGebra yazılımı ile yapılan matematik öğretiminin ortaöğretim öğrencilerinin matematik kaygısı, başarısı ve öğretim teknolojilerine yönelik tutumunun bütüncül bir bakışla araştırıldığı bir çalışmaya rastlanılmamıştır. Bu nedenle araştırmanın alandaki bu boşluğu dolduracağına inanılmaktadır. Araştırmanın ana problemi, "GeoGebra dinamik yazılımı kullanımının 10.sınıf öğrencilerinin akademik başarılarına, matematik kaygısına ve öğretim teknolojilerine yönelik tutumlarına etkileri nasıldır?" şeklinde oluşturulmuştur. Alt problemler ise aşağıda sunulmuştur.

1. GeoGebra yazıımı desteksiz ders işlenen sınıf öğrencilerinin (kontrol grubunun) akademik başarı, matematik kaygısı ve öğretim teknolojilerinin kullanımına yönelik tutum puanları kapsamında ön test-son test puanları arasında anlamlı bir fark var mıdır?

2. GeoGebra yazııımı destekli ders işlenen sınıf öğrencilerinin (deney grubunun) akademik başarı, matematik kaygısı ve öğretim teknolojilerinin kullanımına yönelik tutum puanları kapsamında ön test-son test puanları arasında anlamlı bir fark var mıdır?

3. Kontrol ve deney gruplarının; akademik başarı, matematik kaygısı ve öğretim teknolojilerinin kullanımına yönelik tutum puanları kapsamında erişi puanları arasında anlamlı bir fark var mıdır?

4. Deney grubu öğrencilerinin, matematik dersinde "ikinci Dereceden Fonksiyonlar"konusunda GeoGebra yazılımı kullanımına ilişkin görüşleri nedir?

\section{Yöntem}

Bu çalışmada deneysel yöntem çeşitlerinden olan yarı-deneysel desen kullanılmıştır. Yarı deneysel modeller, bilimsel değer bakımından gerçek deneme modellerinden sonra gelir ve gerçek deneme modellerinin uygulanamadığı durumlarda kullanııı (Karasar, 2015).Bu çalışmada da seçilen okulda sınıflar belli olduğundan ve sınıflarda değişiklik yapılamayacağından dolayı araştırma yarı deneysel desen olarak tasarlanmıştır. Araştırmada yarı deneysel modellerden eşitlenmemiş kontrol gruplu model kullanılmıştır. Bu modelde grupların yansız atama yoluyla eşitlenmeleri için özel bir çaba harcanmaz ancak katılanların benzer nitelikte olmalarına olabildiğince özen gösterilir (Karasar, 2015). Araştırmanın deney deseni Şekil 1. de aşă̆ıda verilmiştir.

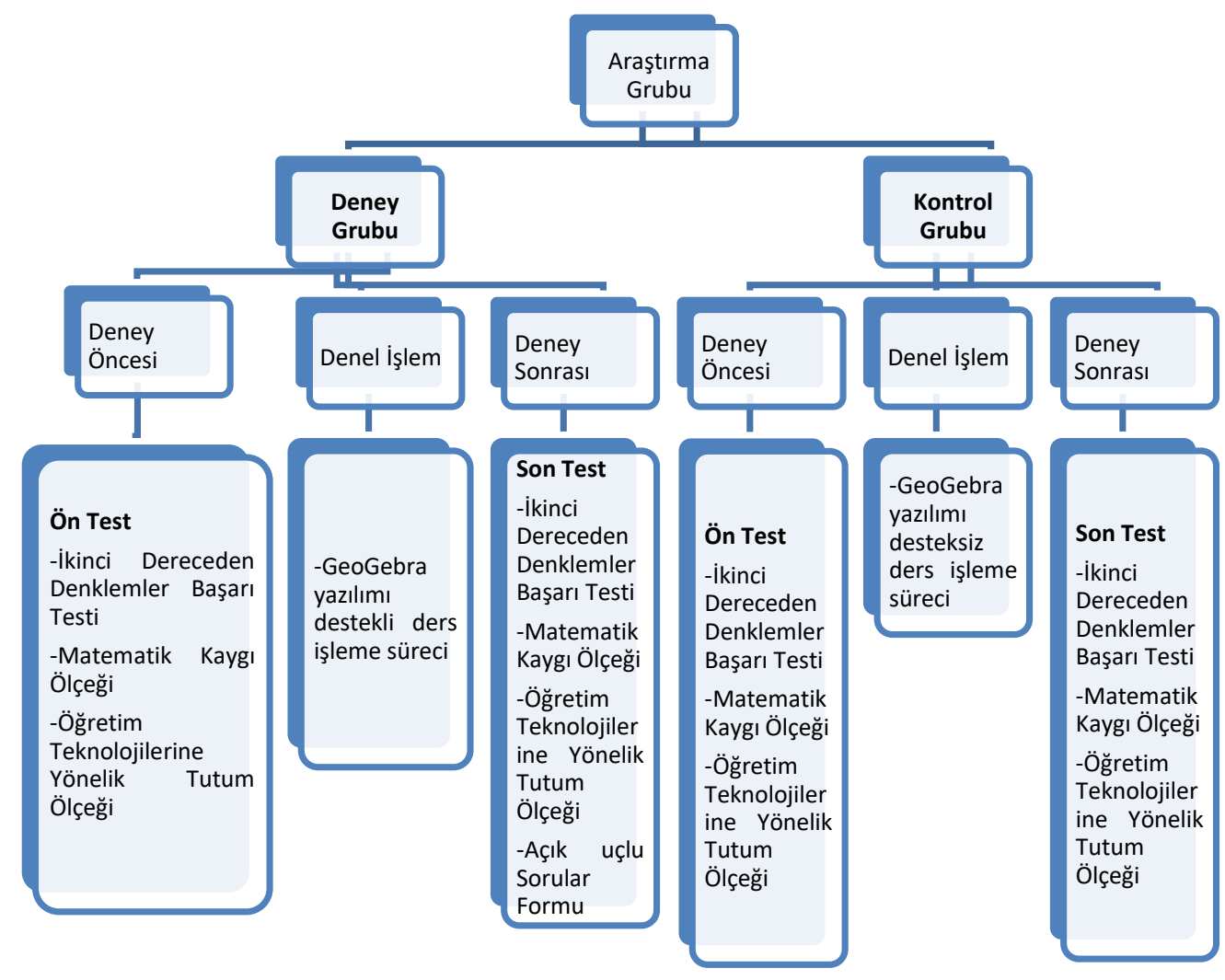

Şekil 1. Araştırmanın Deney Deseni 
Araştırma grubunu bir devlet lisesinde öğrenim gören 10. sınıf öğrencilerinden birbirine en yakın denkliğe sahip iki sınıfın öğrencileri oluşturmuştur. Kontrol ve deney grubunun denkliğini sağlamak için öğrencilerin 9.sınıf matematik dersi karne başarı puanları (deney grubu karne başarı ortalaması $=60$, kontrol grubu karne başarı ortalaması = 64) karşılaştırılmıştır. Kontrol grubunda 14 kadın, 16 erkek toplam 30 öğrenci, deney grubunda ise 16 kadın, 18 erkek öğrenci toplam 34 olmak üzere araştırmaya toplamda 64 öğrenci katılmıştır. Araştırmada uygulama 2016-2017 eğitim öğretim yılının ilk döneminde, 6 hafta boyunca gerçekleştirilmiştir. İkinci dereceden fonksiyonlar konusuna uygun olarak hazırlanan ders deney grubunda GeoGebra dinamik yazılımı kullanılarak, kontrol grubunda ise GeoGebra yazılımı desteksiz işlenmiştir.

\section{Veri Toplama Araçları}

Araştırma grubu öğrencilerinin "ikinci Dereceden Fonksiyonlar" alt öğrenme alanındaki akademik başarılarını ölçmek amacıyla Tataroğlu (2009) tarafından geliştirilen başarı testi kullanılmıştır. Başarı testini geliştiren araştırmacı tarafından yapılan güvenirlik analizinde, başarı testinin KR-20 iç tutarlılık katsayısı 0.854 olarak hesaplanmışken bu araştırmada araştırmacılar tarafından KR-20 iç tutarlılık katsayısı 0.876 olarak hesaplanmıştır. Öğrencilerin matematik kaygısının ölçülmesinde ise Richardson ve Suinn'in (1972) geliştirdiği, Türk kültürüne Baloğlu (2010) tarafından uyarlanan Matematik Kaygısı Ölçeği kullanıımıştır. 30 maddeden oluşan matematik kaygı ölçeğinde, her madde için pek çok, çok, orta, az, hiç seçeneklerinden biri işaretlenmiştir. Ölçekten alınan büyük puan yüksek matematik kaygı seviyesini, küçük puan ise düşük matematik kaygı seviyesini belirtmektedir. Geçerlilik işlemleri kapsamında 5 faktörlü ölçek, toplam varyansın \% 90'ını açıklamaktadır. Alt faktörlerin yükleri .40 ile .78 arasında değişmektedir. Ölçeğin, geliştirenler tarafından bulunan Cronbach Alpha iç tutarlılık katsayı değeri 0.960 iken bu araştırma için araştırmacılar tarafından bulunan Cronbach Alpha iç tutarlılık katsayı değerleri ön test için 0.858 , son test içinse 0.813 'tür. Öğrencilerin öğretim teknolojilerine yönelik tutumlarının ölçülmesinde ise Metin, Yılmaz, Birişçi ve Coşkun (2011) tarafından geliştirilen ölçek kullanılmıştır. Ölçek "Kesinlikle Katılıyorum", " Katılıyorum", "Karasızım", " Katılmıyorum" ve "Kesinlikle Katılmıyorum" beşli Likert şeklinde geliştirilmiştir. Öğretmen adaylarının öğretim teknolojilerine yönelik tutumlarını belirlemeye yönelik ölçekten elde edilen verileri, adayların bu alan yönelik tutumlarını "Çok Yetersiz" (1.00 - 1.79), "Yetersiz" (1.80 - 2.59), "Orta" (2.60 - 3.39) ise, "Iyi" (3.40 - 4.19) ve "Çok iyi" (4.20 - 5.00) kategorileri içinde değerlendirilmiştir. Ölçeğin, geliştirenler tarafından bulunan Cronbach Alpha iç tutarlılık katsayı değeri 0.940 iken bu araştırma için araştırmacılar tarafından bulunan Cronbach Alpha iç tutarlılık katsayı değerleri ön test için 0.501 son test içinse 0.876 'dır. Can'a $(2017$, s.388) göre, Cronbach Alfa değeri -1 ile +1 arasında değer alabilen bir sayıdır ve 1'e ne kadar yaklaşırsa güvenirliğin o oranda arttığı anlamını taşır.

Araştırmada, deney grubu öğrencilerinin matematik derslerinde GeoGebra yazılımının kullanımına ilişkin görüşlerini belirlemek için açık uçlu sorular formu kullanılmıştır. Araştırmacılar tarafından geliştirilen açık uçlu sorular formundaki sorular kapsam geçerliliğinin sağlanması amacıyla GeoGebra dinamik yazılımı ile ilgili alan yazındaki çalışmalar incelenerek hazırlanmıştır. Başlangıçta 8 açık uçlu sorudan oluşan form, kapsam geçerliği için uzman görüşüne sunulmuştur. Alan uzmanlarının görüşleri doğrultusunda form üzerinde gerekli görülen düzeltmeler yapılmış ve soru sayısı 5 olacak şekilde forma son şekli verilmiştir. Sorular aşağıda verilmiştir.

1) Sizce, bu derste Geogebra dinamik yazılımının kullanılmasının olumlu yönleri oldu mu? Olduğunu düşünüyorsunuz lütfen açıklayınız.

2) Sizce, bu derste Geogebra dinamik yazılımının kullanılmasının olumsuz yönleri oldu mu? Olduğunu düşünüyorsunuz lütfen açıklayınız.

3) Geogebra yazılımının en çok hangi özelliklerini sevdiniz?

4) Geogebra yazılımı ile yapılan ders uygulaması süresince sıkıntılarla karşılaştınız mı? Karşılaştıysanız neler olduğunu yazınız.

5) Geogebra dinamik yazılımı gibi programları diğer derslerde de kullanmak ister miydiniz? Cevabınız evet ise en çok kullanmak isteyeceğiniz bir dersin adını yazınız. 


\section{Veri Analizi}

Araştırmada 1. ve 2. alt problemlere ilişkin bulguları elde etmede kullanılacak testlerin seçimi için, deney ve kontrol gruplarına ait ön-test ve son-testten alınan puanların normal dağııım gösterip göstermediği incelenmiştir. Bu incelemede, kontrol grubu 30 ve deney grubu 34 kişiden oluştuğundan, " Kolmogorov-Smirnov " testinden faydalanılmıştır. Deney grubu ve kontrol grubu ön-test puanlarına ait Kolmogorov-Smirnov normal dağılım testi sonuçları Tablo 1'de aşağıda verilmiştir.

Tablo 1. Deney ve Kontrol Grupları Ön-Test Puanlarına Ait Normallik Dağılım Testi Sonuçları

\begin{tabular}{llll}
\hline \multicolumn{1}{c}{ Test (Deney) } & istatistik & sd & $p$ \\
\hline İkinci Dereceden Denklemler Başarı Testi & .14 & 34 & .05 \\
Matematik Kaygı Ölçeği & .08 & 34 & .20 \\
Öğretim Teknolojilerine Yönelik Tutum Ölçeği & .08 & 34 & .20 \\
Test (Kontrol) & istatistik & $s d$ & $p$ \\
İkinci Dereceden Denklemler Başarı Testi & .12 & 30 & .20 \\
Matematik Kaygı Ölçeği & .14 & 30 & .13 \\
Öğretim Teknolojilerine Yönelik Tutum Ölçeği & .17 & 30 & .02 \\
\hline
\end{tabular}

Tablo 1 incelendiğinde, deney grubuna ait ön-test puanlarının normalliğine ilişkin, üç test içinde $p>0.05$ olduğundan sonucun anlamlı olmadığı görülmektedir. Bu sonuç, deney grubu ön-test puanlarının normal dağılım gösterdiğini ortaya koymaktadır. Kontrol grubuna ait ön-test puanlarının normalliğine ilişkin, İkinci Dereceden Denklemler Başarı Testi ve Matematik Kaygı Ölçeğinden alınan puanlar için, p>0.05 olduğundan sonucun anlamlı olmadığı görülmektedir. Bu sonuç, kontrol grubunda İkinci Dereceden Denklemler Başarı Testi ve Matematik Kaygı Ölçeğinden alınan ön-test puanlarının normal dağılım gösterdiğini ortaya koymaktadır. Kontrol grubunda Öğretim Teknolojilerine Yönelik Tutum Ölçeğinden alınan ön test puanlarında $p<0.05$ bulunduğu için normal dağılım bu analizle sağlanamamıştır. Bu nedenle, normallik testi için bulunan basıklık ve çarpıklık değerleri standart hatalarına bölünmüşlerdir ve çarpıklık için 0.688, basıklık içinse 1.013 bulunmuştur. Can'a (2017) göre, normalliği test etmek için çarpıklık katsayısını ve basıklık katsayısı, sırasıyla, çarpıklığın ve basıklığın standart hatasına bölündüğünde, değerler -1.96 ile +1.96 arasında kalırsa dağııım normal kabul edilmektedir (Can, 2017).

Deney ve kontrol grupları son-test puanlarına ait Kolmogorov-Smirnov normallik dağılım testi sonuçları Tablo 2 de aşağıda verilmiştir.

Tablo 2. Deney ve Kontrol Grupları Son-Test Puanlarına Ait Normallik Dağılım Testi Sonuçları

\begin{tabular}{llll}
\hline \multicolumn{1}{c}{ Test(Deney) } & istatistik & sd & $\mathrm{p}$ \\
\hline İkinci Dereceden Denklemler Başarı Testi & .09 & 34 & .20 \\
Matematik Kaygı Ölçeği & .11 & 34 & .20 \\
Öğretim Teknolojilerine Yönelik Tutum Ölçeği & .14 & 34 & .07 \\
Test (Kontrol) & istatistik & sd & $\mathrm{p}$ \\
İkinci Dereceden Denklemler Başarı Testi & .09 & 00 & .20 \\
Matematik Kaygı Ölçeği & .12 & 00 & .20 \\
Öğretim Teknolojilerine Yönelik Tutum Ölçeği & .12 & 30 & .20 \\
\hline
\end{tabular}

Tablo 2 incelendiğinde, deney grubuna ait son-test puanlarının normalliğine ilişkin olarak, üç test içinde $p>0.05$ olduğundan sonucun anlamlı olmadığı görülmektedir. Bu sonuç, deney grubu son-test puanlarının normal dağılım gösterdiğini ortaya koymaktadır. Kontrol grubuna ait son-test puanlarının normalliğine ilişkin olarak Tablo 2 incelendiğinde, üç test içinde $p>0.05$ olduğundan sonucun anlamlı olmadığı görülmektedir. Bu sonuç, kontrol grubu son-test puanlarının normal dağııım gösterdiğini ortaya koymaktadır. Birinci ve ikinci alt problemlerden elde edilen verilerin analizi, gerekli koşullar sağlandığı için ilişkili örneklemler için t-testi ile yapılmıştır. 
Üçüncü alt problemden elde edilen verilerin analizi için, karışık ölçümler için iki yönlü (faktörlü) varyans analizi yapılmasına karar verilmiştir. i̇ki yönlü varyans analizinin güvenilir sonuçlar verebilmesi için, şu koşulların sağlanmış olması gerekir (Can, 2017).

1.Veriler, her bir alt grup içinde(deney ve kontrol gruplarının, ön test ve son testlerinde olmak üzere 4 ayrı grup için) normal dağıı özelliklerinin taşımalıdır. Her iki grupta da yapılan iki ölçüm için verilerin normal dağılım özelliği gösterdiği yukarıda verilmiştir.

2.Aynı anda birden fazla grupta yapılan her bir ölçümde, grupların varyansı homojen olmalıdır. Bunun kontrolü, "grupların varyansları arasında anlamlı fark yoktur" şeklindeki yokluk hipotezini sınayan Levene Testi ile yapılmıştır. Levene testi sonuçları Tablo 3'de verilmiştir.

Tablo 3. Grupların Varyans Homojenliği Tablosu

\begin{tabular}{|c|c|c|c|c|c|}
\hline \multirow[t]{2}{*}{ Ölçüm } & & \multicolumn{3}{|c|}{$\begin{array}{l}\text { Levene's Test of Equality of } \\
\text { Error Variancesa } \\
\end{array}$} & \multirow[b]{2}{*}{ Sig. } \\
\hline & & $\mathrm{F}$ & df1 & df2 & \\
\hline \multirow[t]{2}{*}{ Matematik Kaygı Ölçeği } & Öntest & .170 & 1 & 65 & .681 \\
\hline & Sontest & .430 & 1 & 65 & .514 \\
\hline \multirow{2}{*}{$\begin{array}{l}\text { Öğretim Teknolojilerine Yönelik } \\
\text { Tutum Ölçeği }\end{array}$} & Öntest & 1.523 & 1 & 65 & .222 \\
\hline & Sontest & 1.724 & 1 & 65 & .194 \\
\hline \multirow[t]{2}{*}{ Matematik Başarı Testi } & Öntest & 2.465 & 1 & 65 & .121 \\
\hline & Sontest & 2.466 & 1 & 65 & .121 \\
\hline
\end{tabular}

Levene testi sonucunda,; matematik kaygı ölçeği, öğretim teknolojilerine yönelik tutum ölçeği ve matematik başarı testinden alınan ön test ve son test puanları için varyanslar arası fark olmadığı yokluk hipotezi kabul edilerek, ( $p>0.05$ ) varyansların eşitliği koşulu sağlanmıştır.

3.Ölçüm gruplarının ikili kombinasyonları için grupların kovaryansları arasında anlamlı fark olmamalıdır. Bu durum Kovaryans Matrislerinin Eşitliği testi ile kontrol edilmiştir. Aşağıda Box testi sonuçları Tablo 4 de verilmiştir.

Tablo 4. Kovaryans Matrislerinin Eşitliği Test Sonuçları Tablosu

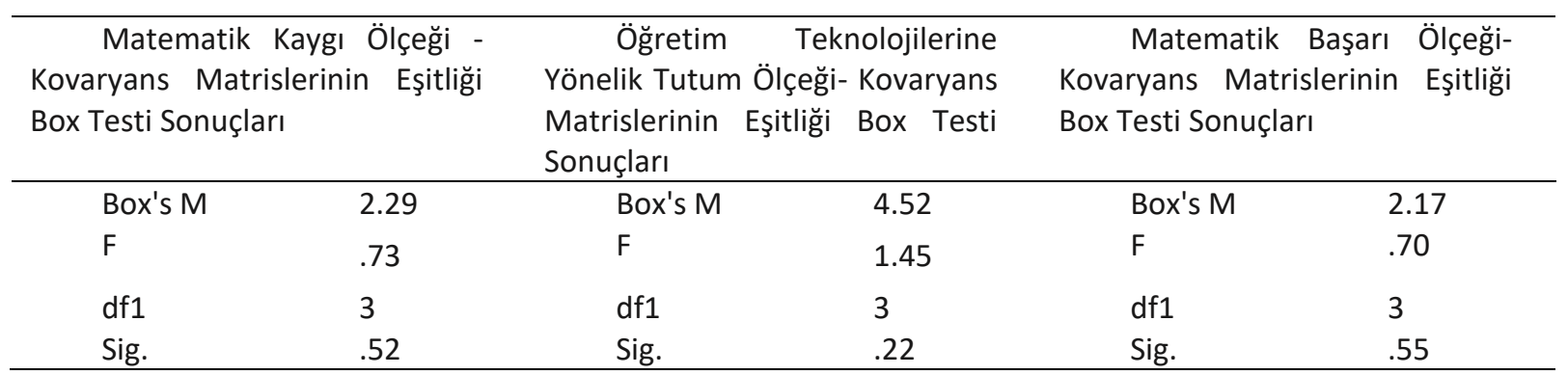

Tablo 4 incelendiğinde, Box testi ile, matematik kaygı ölçeği, öğretim teknolojilerine yönelik tutum ölçeği ve matematik başarı testinde ölçüm gruplarının ikili kombinasyonları için grupların kovaryansları arasında anlamlı fark yoktur şeklindeki yokluk hipotezi sınanmış ve kovaryanslar arasında anlamlı bir fark yoktur hipotezi ( $p>0.05$ ) kabul edilmiştir. Üçüncü alt problemden elde edilen verilerin analizi için karışık ölçümler için iki yönlü varyans analizinin tüm koşulları sağlandığından analiz yapılmıştır.

Açık uçlu soruların değerlendirilmesi için ise içerik analizi yapılmıştır. Öğrencilerin vermiş oldukları cevapları iki farklı uzman tarafından bağımsız olarak temalarına ayırmıs ve daha sonra bu temalar karşılaştırılmıştır. Araştırmanın güvenirliğinin hesaplanması için Miles ve Huberman'ın önerdiği kodlayıcı güvenirliği formülü kullanılmıştır. Miles 
Huberman kodlayıcı güvenirliği formülüne göre güvenirlik yüzdesi, kodlayıcıların görüş birliğine vardığı kod sayısının, toplam görüşbirliği + görüş ayrılığı sayısına bölümünden elde edilir ve en az $\% 80$ güvenirliğinin elde edilmesi beklenir (Miles ve Huberman, 2016). Açık uçlu sorular formunda bulunan beş farklı soru iki ayrı uzman tarafından ayrı ayrı incelenmiştir. Daha sonra, bu veriler Güvenirlik = Görüş Birliği/ Görüş Birliği+Görüş Ayrılığı formülü kullanılarak her bir soru için güvenirlik hesaplanmıştır. Açık uçlu sorulara verilen cevapların içerik analizinde kodlayıcı güvenirliği formülünün uygulanması sonucunda ortaya çıkan değerler Tablo 5 de aşağıda verilmiştir.

Tablo 5. Açık Uçlu Sorular Formu Güvenirlik Katsayı Değerleri

\begin{tabular}{llllll}
\hline $\begin{array}{l}\text { Soru } \\
\text { Numarası }\end{array}$ & 1 & 2 & 3 & 4 & 5 \\
\hline $\begin{array}{l}\text { M.H. } \\
\text { Güvenirlik }\end{array}$ & 0.89 & 0.83 & 0.87 & 1.0 & 1.0 \\
$\begin{array}{l}\text { Katsayı } \\
\text { Değeri }\end{array}$ & & & & & \\
\hline
\end{tabular}

\section{Geçerlik ve Güvenirlik Çalışması}

Araştırmanın genelinde güvenilirliği sağlamak amacıyla kontrol ve deney gruplarının bir önceki yıl matematik akademik başarı ortalamaları dikkate alınmış ve gruplar birbirine en yakın ortalamaya sahip sınıflardan seçilmiştir. Ayrıca araştırmada kullanılan hazır veri toplama araçlarının iç tutarlııı katsayıları araştırma süresince yapılan ölçümlere özel olarak hesaplanmıştır. Nicel verilerde kullanılacak analizlerin sayıltıları dikkate alınarak analizler gerçekleştirilmiştir. Araştırmacılar tarafından geliştirilen açık uçlu sorular formuna verilen cevaplardan elde edilen kodların güvenilirliği için kodlayıcı güvenirliği formülü kullanılmıştır. Ayrıca her iki grup üzerinde de araştırmanın uygulaması, araştırmacılardan biri olan ortaöğretim matematik öğretmeni tarafından yürütülmüş, deney grubunda kullanılan GeoGebra dinamik yazılımının kullanımı kapsamında aynı araştırmacı yeteri kadar bilgiye ve deneyime sahip olarak süreci başlatmıştır.

Araştırmanın genelinde geçerliliğin sağlanması amacıyla, araştırma konusuna ilişkin detaylı veri toplanması amacıyla araştırmada sadece nicel veriler değil nitel verilerde toplanmıştır. Nicel veri toplamak için kullanılacak hazır veri toplama araçlarının araştırma konusuna uygunluğu incelenmiş, farklı veri toplama araçlarının içindeki maddelere bakılmış araştırma konusu ile ilişkili maddelerin bulunduğu en uygun veri toplama araçlarına karar verilmiştir. Araştırmacılar tarafından geliştirilen nitel veri toplama aracında ise soruların kapsam geçerliliği için öncelikle alan yazın taranmış ardından geliştirilen sorular için uzman kanısı alınmıştır.

\section{Deneysel Süreç}

Araştırmada deneysel süreç 6 hafta öğrencilerin kendi sınıflarında sürmüştür. İlk aşamada öğrencilerin ortaöğretim 10. Sınıf matematik derslerinde kullanabilecekleri GeoGebra yazılımı ile hazırlanmış ders materyalleri tasarlanmıştır. Ders materyallerinin hazırlanmasından sonra, 1.hafta deney ve kontrol gruplarına ön-test uygulanmıştır. Dersler her iki grupta da araştırmacı tarafından işlenmiştir. Deney grubundaki öğrencilere deneysel süreç aşamasında kullanacakları GeoGebra dinamik yazılımı ile ilgili uygulamalı tanıtım dersi verilmiştir. İlk olarak GeoGebra dinamik yazılımının etkileşimli tahtaya, dizüstü bilgisayara ve tabletlere nasıl kurulduğu ile ilgili uygulama, araştırmacı tarafından gösterilmiş daha sonra öğrencilerden kurmaları istenmiştir. Deney grubundaki öğrencilere GeoGebra'nın menü araçlarını nasıl kullanacakları etkileşimli tahtada gösterilmiş ve daha sonra kendilerinin yazııımdaki menüleri hem bireysel hem yardımlaşarak kullanabilmeleri için gerekli süre tanınmıştır. Deneysel süreçte 4 hafta boyunca, deney ve kontrol grubunda, ikinci dereceden fonksiyonlar alt öğrenme alanı ile ilgili 2 kazanım işlenmiştir. Bu kazanımlar aşağıda belirtilmiştir.

a)ikinci dereceden bir değişkenli fonksiyonu açıklar ve grafiğini çizer.

b)ikinci derece fonksiyonlarla ilgili problemleri çözer.

Kazanımlara yönelik kavramların öğretiminde deney grubunda, GeoGebra yazııımı yoluyla hazırlanan materyalleri ve çalışma yapraklarında bulunan yönergeleri kullanarak ders işlenmiştir. Kontrol grubunda ise öğretmen gerekli çizimleri kendi yapıp daha çok tahtayı kullanarak kavramları öğrencilere öğretmeye çalışış, öğrenciler ise uygulamaları yine tahta üzerinde ve kendi defterlerini kullanarak yapmışlardır. Araştırmacı her iki 
grupta da aynı içeriğe uygun olarak dersi sürdürmüştür. Ders işleniş süreci tamamlandıktan sonra 6. hafta sonunda araştırmacılar her iki gruba da son-testleri uygulamıştır. Deney grubuna da açık uçlu soru formu ayrıca uygulanmıştır.

\section{Bulgular}

\section{Birinci Alt Probleme Ait Bulgular}

Araştırmanın birinci alt problemi, "GeoGebra yazılımı desteksiz ders işlenen sınıf öğrencilerinin (kontrol grubunun) akademik başarı, matematik kaygısı ve öğretim teknolojilerinin kullanımına yönelik tutum puanları kapsamında ön test-son test puanları arasında istatiksel olarak anlamlı bir fark var mıdır?' şeklindedir. Kontrol grubunda matematik kaygı ölçeğinden alınan ön test ve son test puanlarına ilişkin bulgular Tablo 6' da verilmiştir.

Tablo 6. Kontrol Grubunda Matematik Kaygı Ölçeğinden Alınan Ön Test ve Son Test Puanları

\begin{tabular}{lllllll}
\hline Ölçüm & $N$ & Ortalama & S.Sapma & sd & t & p \\
\hline Ön & 30 & 71,66 & 15,38 & & & \\
Son & 30 & 63,10 & 14,95 & 29 & 2,67 & 0,01 \\
\hline \multicolumn{2}{r}{} & $\mathrm{p}<0.05$ & & & &
\end{tabular}

Analiz sonuçlarına göre, kontrol grubunda bulunan öğrencilerin matematik kaygısı ölçeğinden aldıkları puanların ön test ortalaması 71,66 ve son test ortalaması 63,10' dur. Kontrol grubu öğrencilerinin "Matematik Kaygı Ölçeği" nden aldıkları ön test ve son test puanları arasında son test lehine anlamlı bir farklılık olduğu görülmektedir $[\mathrm{t}(29)=2,67, \mathrm{p}<0.05]$.

Kontrol grubuna ait öğretim teknolojilerine yönelik tutum ölçeğinden alınan ön test ve son test puanlarına ilişkin bulgular Tablo 7'de verilmiştir.

Tablo 7. Kontrol Grubunda Öğretim Teknolojilerine Yönelik Tutum Ölçeğinden Alınan Ön Test ve Son Test Puanları

\begin{tabular}{lllllll}
\hline Ölçüm & $N$ & Ortalama & S.Sapma & sd & t & $p$ \\
\hline Ön & 30 & 116,80 & 8,03 & 29 & - & 0,00 \\
Son & 30 & 127,33 & 16,86 & & 3,16 & \\
\hline \multicolumn{2}{c}{$p<0,05$} & & & & &
\end{tabular}

Analiz sonuçlarına göre, kontrol grubunda bulunan öğrencilerin öğretim teknolojilerine yönelik tutum ölçeğinden aldıkları puanların ön test ortalaması 116,80 ve son test ortalaması 127,33 tür. Kontrol grubu öğrencilerinin Öğretim Teknolojilerine Yönelik Tutum Ölçeğinden aldıkları ön test ve son test puanları arasında anlamlı bir farklılık olduğu görülmektedir [t(29)=-3,16, $p<0.05]$.

Kontrol Grubunda ikinci dereceden fonksiyonlar başarı testinden alınan ön test ve son test puanlarına ilişkin bulgular Tablo 8'de verilmiştir.

Tablo 8. Kontrol Grubunda İkinci Dereceden Fonksiyonlar Başarı Testinden Alınan Ön Test ve Son Test Puanları

\begin{tabular}{lllllrl}
\hline Ölçüm & $N$ & Ortalama & S.Sapma & Sd & $t$ & $p$ \\
\hline Ön & 30 & 8,10 & 3,24 & & - & 0,00 \\
Son & 30 & 13,73 & 4,23 & 29 & 14,51 & \\
\hline$p<0,05$ & & & & &
\end{tabular}

Analiz sonuçlarına göre, kontrol grubunda bulunan öğrencilerin ikinci dereceden fonksiyonlar başarı testinden aldıkları puanların ön test ortalaması 8,10 ve son test ortalaması 13,73 dir. Kontrol grubu öğrencilerinin "ikinci Dereceden Fonksiyonlar Başarı Testi"nden aldıkları öntest ve son test puanları arasında, son test puanları lehine anlamlı bir farklılık olduğu görülmektedir [t(29)=-14,51, $\mathrm{p}<0.05]$. 


\section{İkinci Alt Probleme Ait Bulgular}

Araştırmanın ikinci alt problemi "GeoGebra yazııımı kullanılan sınıf öğrencilerinin (deney grubunun) akademik başarı, matematik kaygısı ve öğretim teknolojilerinin kullanımına yönelik tutum puanları kapsamında ön test-son test puanları arasında anlamlı bir fark var mıdır?" şeklindedir. Deney grubunda matematik kaygı ölçeğinden alınan ön test ve son test puanlarına ait bulgular Tablo 9'da verilmiştir.

Tablo 9. Deney Grubunda Matematik Kaygı Ölçeğinden Alınan Ön Test ve Son Test Puanları

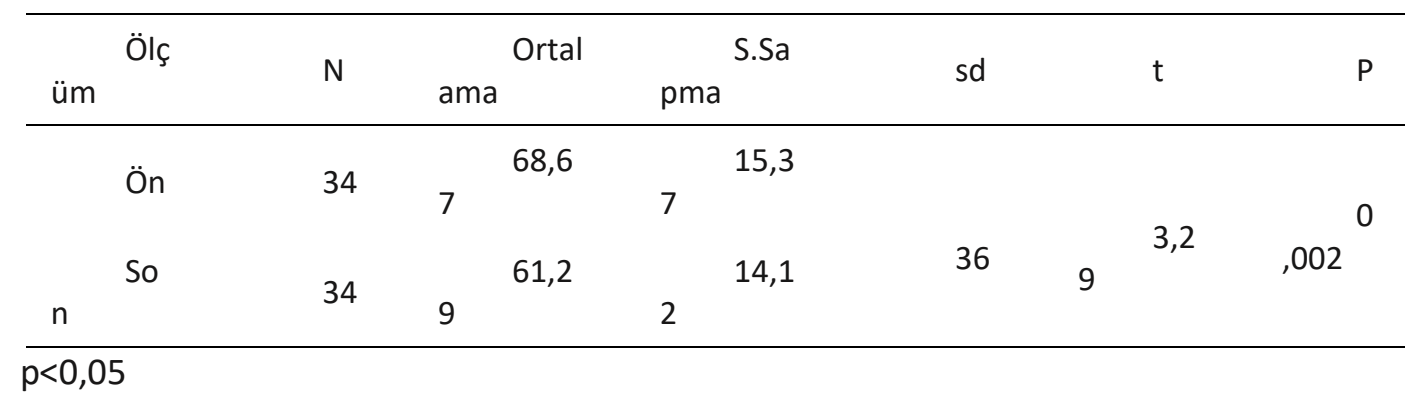

Analiz sonuçlarına göre, deney grubunda bulunan öğrencilerin matematik kaygısı ölçeğinden aldıkları puanların ön test ortalaması 68,67 ve son test ortalaması $61,29^{\prime}$ dur. Deney grubu öğrencilerinin Matematik Kaygı Ölçeğinden aldıkları ön test ve son test puanları arasında, son test puanları lehine anlamlı bir farklılık olduğu görülmektedir $[t(36)=3,29, p<0.05]$.

Deney grubunda öğretim teknolojilerine yönelik tutum ölçeğinden alınan ön test ve son test puanlarına bulgular Tablo $10^{\prime}$ da verilmiştir.

Tablo 10. Deney Grubunda Öğretim Teknolojilerine Yönelik Tutum Ölçeğinden Alınan Ön Test ve Son Test Puanları

\begin{tabular}{lllllll}
\hline Ölçüm & $N$ & Ortalama & S.Sapma & sd & $t$ & $p$ \\
\hline Ön & 34 & 109,89 & 8,58 & 36 & - & 0,25 \\
Son & 34 & 112,35 & 14,38 & & 1,15 & \\
\hline
\end{tabular}

$p<0,05$

Analiz sonuçlarına göre, deney grubunda bulunan öğrencilerin öğretim teknolojilerine yönelik tutum ölçeğinden aldıkları puanların ön test ortalaması 109,89 ve son test ortalaması 112,35 tür. Deney grubu öğrencilerinin “Öğretim Teknolojilerine Yönelik Tutum Ölçeği" neden aldıkları ön test ve son test puanları arasında, anlamlı bir farklılık olmadığı görülmektedir [t(36)=-1,15, p >.05].

Deney grubunda ikinci dereceden fonksiyonlar başarı testinden alınan ön test ve son test puanlarına ait bulgular Tablo $11^{\prime}$ de verilmiştir.

Tablo 11. Deney Grubunda İkinci Dereceden Fonksiyonlar Başarı Testinden Alınan Ön Test ve Son Test Puanları

\begin{tabular}{lllllll}
\hline Ölçüm & $N$ & Ortalama & S.Sapma & Sd & t & $P$ \\
\hline Ön & 34 & 8,13 & 3,85 & 36 & - & 0,000 \\
Son & 34 & 15,16 & 5,34 & & 16,31 & \\
\hline
\end{tabular}

$$
p<0,05
$$

Analiz sonuçlarına göre, deney grubunda bulunan öğrencilerin ikinci dereceden fonksiyonlar başarı testinden aldıkları puanların ön test ortalaması 8,13 ve son test ortalaması 15,16 dir. Deney grubu öğrencilerinin "ikinci 
Dereceden Fonksiyonlar Başarı Testi" nden aldıkları ön test ve son test puanları arasında, son test puanları lehine anlamlı bir farklılık olduğu görülmektedir [t(36)=-16,31, $p<.05]$.

\section{Üçüncü Alt Probleme Ait Bulgular}

Araştırmanın üçüncü alt problemi “Kontrol ve deney gruplarının; akademik başarı, matematik kaygısı ve öğretim teknolojilerinin kullanımına yönelik tutum puanları kapsamında erişi puanları arasında anlamlı bir fark var mıdır? "şeklindedir.

“Matematik Kaygı Ölçeği"nden elde edilen verilerin karışık ölçümlerde iki yönlü varyans analizi grup-içi etkiler testi sonuçları aşağıda Tablo 12'de verilmiştir. Ön-test ve son-test deney ve kontrol gruplarının kestirilen ortalamaları Şekil 2'de verilmiştir. Karışık ölçümler için iki yönlü varyans analizi sonuçlarına göre, matematik kaygı ölçeğinden alınan erişi puanları açısından deney grubu ve kontrol grubu arasında anlamlı bir fark yoktur $(F=.097, p>.05)$

\section{Tablo 12. Grup-içi Etkiler Testine İlişkin Bulgular Tablosu}

\begin{tabular}{lcclll}
\hline DeğişkenlikKaynağı & $\begin{array}{l}\text { Tip III Kareler } \\
\text { toplamı }\end{array}$ & df & $\begin{array}{l}\text { Kareler } \\
\text { Ortalaması }\end{array}$ & $\mathrm{F}$ & $\mathrm{p}$ \\
\hline Ölçüm & 2106,05 & 1 & 2106,05 & 17,54 & .00 \\
Ölçüm * GRUP & 11,69 & 1 & 11,69 & .097 & .75 \\
Hata(ölçüm) & 7804,03 & 65 & 120,06 & & \\
\hline
\end{tabular}

$p<0,05$

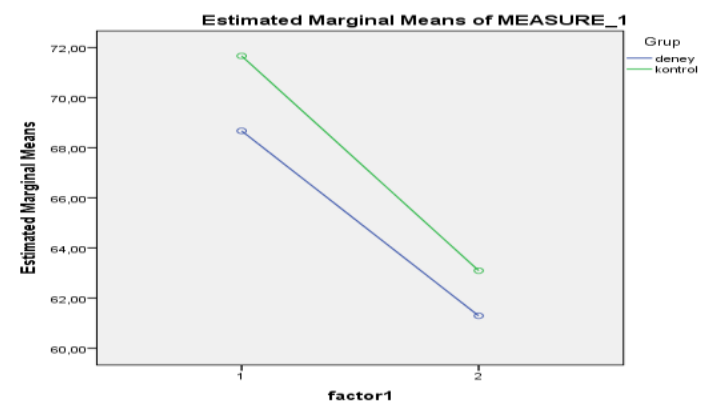

Şekil 2. Ön Test Son Test Deney Ve Kontrol Gruplarının Kestirilen Ortalamaları

Öğretim teknolojilerine yönelik tutum ölçeğinden elde edilen verilerin karışık ölçümlerde iki yönlü var-yans analizi grup-içi etkiler testi sonuçları aşağıda Tablo 13' de verilmiştir. Ön-test ve son-test deney ve kontrol gruplarının kestirilen ortalamaları Şekil 3'de verilmiştir. Karışık ölçümler için iki yönlü varyans analizi sonuçlarına göre, öğretim teknolojilerine yönelik tutum ölçeğinden alınan erişi puanları açısından deney grubu ve kontrol grubu arasında, kontrol grubu lehine anlamlı bir fark vardır ( $F=4,471, p<0.05)$.

Tablo 13 Grup-i̇çi Etkiler Testine illişkin Bulgular Tablosu

\begin{tabular}{lllcll}
\hline Değişkenlik Kaynağı & $\begin{array}{l}\text { Tip III Kareler } \\
\text { Toplamı }\end{array}$ & df & $\begin{array}{l}\text { Kareler } \\
\text { Ortalaması }\end{array}$ & F & p \\
\hline Ölçüm & 1398,37 & 1 & 1398,37 & 11,57 & .00 \\
Ölçüm * GRUP & 539,98 & 1 & 539,98 & 4,47 & .03 \\
Hata(ölçüm) & 7850,32 & 65 & 120,77 & & \\
\hline
\end{tabular}

$\mathrm{p}<0.05$ 


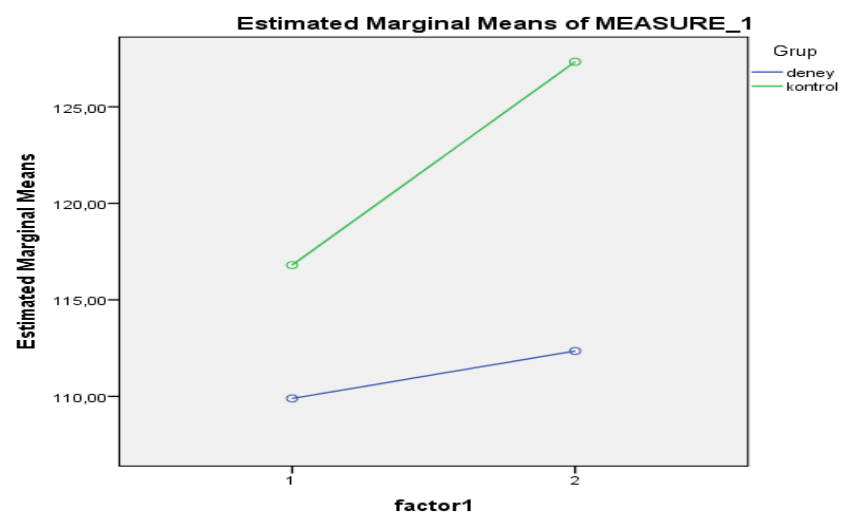

Şekil 3.Ön-Test Son-Test Deney Ve Kontrol Gruplarının Kestirilen Ortalamaları

Matematik başarı testinden alınan elde edilen verilerin karışık ölçümlerde iki yönlü varyans analizi grup-içi etkiler testi sonuçları aşağıda Tablo 14'de verilmiştir. Ön-test ve son-test deney ve kontrol gruplarının kestirilen ortalamaları Şekil 4'te verilmiştir. Karışık ölçümler için iki yönlü varyans analizi sonuçlarına göre, matematik başarı testinden alınan erişi puanları açısından deney grubu ve kontrol grubu arasında, deney grubu lehine anlamlı bir fark vardır ( $F=5.534$, $\mathrm{p}<0.05)$.

Tablo 14. Grup-içi Etkiler Testine iliş̧kin Bulgular Tablosu

\begin{tabular}{lllllll}
\hline Değişkenlik Kaynağı & $\begin{array}{l}\text { Tip } \\
\text { Kareler } \\
\text { Toplamı }\end{array}$ & III & df & $\begin{array}{l}\text { Kareler } \\
\text { Ortalaması }\end{array}$ & F & p \\
\hline Ölçüm & 1327,73 & 1 & 1327,73 & 456,7 & .00 \\
Ölçüm * GRUP & 16.09 & 1 & 16.09 & 5.53 & .02 \\
Hata(ölçüm) & 188.97 & 65 & 2.90 & & \\
\hline
\end{tabular}

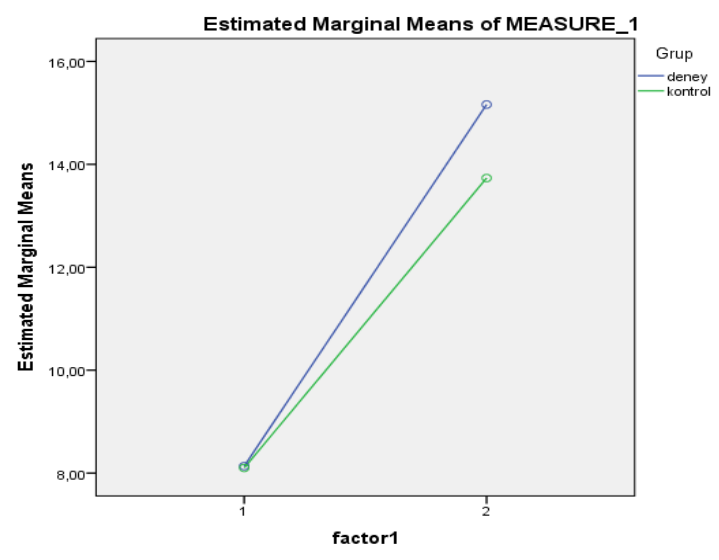

Şekil 4. Ön-Test Son-Test Deney Ve Kontrol Gruplarının Kestirilen Ortalamaları

\section{Dördüncü Alt Probleme Ait Bulgular}

Dördüncü alt problem için deney grubundaki öğrencilere açık uçlu soru formunda bulunan beş soru sorulmuştur ancak aşağıda belirtilen üç soru dışındaki iki sorunun analizi sonucunda kayda değer veri toplanamadığından sadece üç soruya verilen cevaplardan elde edilen bulgular sunulmuştur. Öğrencilere sorulan birinci soru "Sizce, bu derste GeoGebra dinamik yazııımının kullanılmasının olumlu yönleri oldu mu? Olduğunu düşünüyorsanız lütfen açıklayınız." şeklindedir. Öğrencilerin \%98 si (N=33) derste GeoGebra yazılımının kullanılmasının olumlu olduğu cevabını verirken, $\% 2$ si ( $N=1$ ) olumsuz olduğu cevabını vermiştir. Verilen cevaplardan elde edilen kodlar Tablo 15'te sunulmuştur. 
Tablo 15. GeoGebra Dinamik Yazılımının Kullanılmasının Olumlu Yönlerine Ilişkin Kodlar ( $N=34)$

\begin{tabular}{|c|c|c|}
\hline Kodlar & $f$ & $\%$ \\
\hline Etkili öğrenme & 15 & 34 \\
\hline Matematiği eğlenceli hale getirme & 5 & 12 \\
\hline Öğrenmede kolaylık & 5 & 12 \\
\hline Kalıcı öğrenme & 5 & 12 \\
\hline Aktif öğrenme & 5 & 12 \\
\hline Görsellik & 4 & 9 \\
\hline Öğrenmede hız & 3 & 7 \\
\hline Dikkat çekme & 1 & 2 \\
\hline Toplam & 43 & 100 \\
\hline
\end{tabular}

Tablo 15 incelendiğince, öğrencilerin cevapları 8 kod ile sınıflandırılmıştır. Öğrenciler GeoGebra dinamik yazılımının en çok sırasıyla etkili öğrenmelerine yardımcı olduğunu, matematiği eğlenceli hale getirdiğini, öğrenmede kolaylık sağladığını ve kalıcı ile aktif öğrenmelerine destek olduğunu ifade etmişlerdir. Deney grubunda bulunan iki öğrencinin bu soruya yönelik ifadeleri ise şu şekilde olmuştur: "Evet oldu. Daha iyi öğrendim ve matematik daha eğlenceli oldu.", "Evet oldu. Geogebra sayesinde konuları daha iyi ve daha hızlı öğrendim."

Öğrencilere sorulan ikinci soru "GeoGebra yazılımının en çok hangi özelliklerini sevdiniz?" sorusuna verilen cevaplardan elde edilen kodlar Tablo 16'da verilmiştir.

Tablo 16. GeoGebra Dinamik Yazılımının En Çok Sevilen Özelliklerine ilişkin Kodlar (N=34)

\begin{tabular}{lcc}
\hline Kodlar & $\mathrm{f}$ & $\%$ \\
\hline Görsellik & 17 & 43 \\
& & \\
Pratik & 7 & 18 \\
Etkili öğrenme sağlama & 5 & 12 \\
Öğrenmede hız sağlama & 5 & 12 \\
Eğlenceli olma & 2 & 5 \\
Aktif olma & 2 & 5 \\
Teknolojik bir araç olma & 2 & 5 \\
Toplam & 40 & 100 \\
\hline
\end{tabular}

Tablo 16 incelendiğinde, öğrencilerin cevapları 7 kod ile sınıflandırılmıştır. Öğrenciler GeoGebra dinamik yazılımının kullanımına ilişkin en çok sevdikleri özellikleri sırasıyla; görsellik sağladığı, pratik bir uygulama olduğu, etkili öğrenmeye destek olduğu ve öğrenmede hı sağladığı kodlarını ifade etmişlerdir. Deney grubunda bulunan iki öğrencinin bu soruya yönelik ifadeleri ise şu şekilde olmuştur: "Boşluğa denklemi yazdığımızda bize direk çiziyor olması özelliğini sevdim.", "Konuları daha iyi anlamamızı sağladı. Zaman açısından da çok iyiydi."

Öğrencilere sorulan üçüncü soru "GeoGebra gibi farklı dinamik yazılımları diğer derslerde de kullanmak ister miydiniz?" Cevabınız evet ise en çok kullanmak isteyeceğiniz bir dersin adını yazınız? Şeklindedir. Öğrencilerin \% 88 $\mathrm{i}(\mathrm{N}=30)$ bu soruya evet cevabını verirken, \% $12 \mathrm{si}(\mathrm{N}=4)$ hayır cevabını vermiştir. 
Tablo 17. Geogebra Gibi Dinamik Yazılımların Kullanılmasının İstenildiği Farklı Derslere

\author{
iliş̧kin Kodlar ( $\mathrm{N}=\mathbf{3 4})$
}

\begin{tabular}{lll}
\hline Kodlar & $\mathrm{f}$ & $\%$ \\
\hline Fizik & 23 & 77 \\
Kimya & 4 & 14 \\
Biyoloji & 1 & 3 \\
Tarih & 1 & 3 \\
Dil ve Anlatım & 1 & 3 \\
Toplam & 30 & 100 \\
\hline
\end{tabular}

Tablo 17 incelendiğinde, öğrencilerin cevapları 5 kod ile sınıflandırılmıştır. Öğrenciler, GeoGebra gibi yazılımları en çok sırasıyla fizik ve kimya derslerinde de kullanmak istediklerini vurgulamışlardır.

\title{
4. Tartışma ve Sonuç
}

Elde edilen bulgulara göre kontrol grubu öğrencilerinin başarı testinden ön-test ve son-test puanlarının ortalaması arasında anlamlı bir farklılık olduğu görülmektedir. Bu fark ön-test ve son-test arasında öğrenmenin gerçekleştiğini göstermektedir. Bu durum kontrol grubunda GeoGebra yazılımı kullanılmadan ders programında belirtildiği şekilde yapılan öğretime, öğrencilerin alışık olması sebep olarak gösterilebilir. Literatüre bakıldığında Öz (2015), Martnize (2017), Mercan (2012), Balcı Şeker (2014) ve Kepçeoğlu'nun (2010) yaptıkları çalışmaların bulguları da, bu araştırmanın sonucu ile örtüşmektedir. Araştırmada elde edilen bir diğer sonuç, kontrol grubundaki öğrencilerin matematik kaygı ölçeğinden uygulama öncesinde ve sonrasında aldıkları puanlar arasında son test lehine anlamlı bir fark olduğudur. Bu sonuç GeoGebra desteksiz ve ders kitabı kullanılarak işlenen derslerin, öğrencilerin matematik kaygısına olumlu etki ettiği şeklinde yorumlanabilir. Bu sonucun, öğrencilerin alışık olduğu bir öğretim yöntemiyle işlenen ders sürecinde kendilerini daha rahat hissetmelerinden kaynaklandığı düşünülebilir. Ancak, Özçakır Sümen (2013), simetri konusunun GeoGebra yazılımıyla öğretiminin öğrencilerin matematik başarısına ve kaygısına olan etkisini belirlemek için yaptığı çalışmada, kontrol grubundaki öğrencilerin matematik kaygı ölçeğinden uygulama öncesinde ve sonrasında aldıkları puanlar arasında anlamlı bir fark olmadığı sonucuna ulaşmıştır. Bu bulgu, araştırmanın sonucu ile örtüşmeyen farklı bir bulgudur. Bunun nedeni olarak araştırmacıların bu araştırmayı ilkokul dördüncü sınıf öğrencileri ile yürütmüş olmalarından kaynaklandığı düşünülebilir. Araştırmada elde edilen bir diğer sonuç, kontrol grubunda bulunan öğrencilerin, GeoGebra yazılımı desteksiz ders işlenişinden önce, öğretim teknolojilerine yönelik tutum ölçeğinden aldıkları puanlar ile ders işlendikten sonra ölçekten aldıkları puanlar arasında istatistiksel olarak son test lehine anlamlı bir farklılık olduğudur. Bu sonuç kontrol grubunda işlenen derslerin, öğrencilerin öğretim teknolojilerine yönelik tutumunu olumlu etkilediği şeklinde yorumlanabilir. Bunun nedeni olarak ta bu öğrencilerin yaş grubu itibariyle bilgi ve iletişim teknolojilerini ders dışında da sürekli kullandığı, bu tür teknolojilerle etkileşimlerinin hiç kesilmediği şeklinde düşünülebilir.

Elde edilen bulgulara göre deney grubu öğrencilerinin başarı ön ve son testinden aldıkları puanlarının ortalaması arasında anlamlı bir farklılık olduğu görülmektedir. Bu durum, GeoGebra destekli ders işlenişi sonrasında öğrencilerin son testten aldıkları puanların ortalamalarında artış olduğu ve bu öğretim yöntemi ile akademik başarılarının arttığı ve öğrenmenin gerçekleştiği şeklinde yorumlanabilir. Literatüre bakıldığında Khalil, Farooq, Çakıroğlu, Khalil ve Khan (2018), Taş (2016), Çetin, Erdoğan ve Yazlık (2015), Kllogjeri (2015), Vasquez (2015), Balcı Şeker (2014), Thambi ve Eu (2013) ile Mukurı'nin (2016) yaptıkları araştırmaların bulgularıyla paralellik göstermektedir. Araştırmada elde edilen bir diğer sonuç, deney grubundaki öğrencilerin matematik kaygı ölçeğinden uygulama öncesinde ve sonrasında aldıkları puanlar arasında anlamlı bir fark olduğudur. Bu sonuç GeoGebra dinamik yazılımı kullanılarak işlenen derslerin, öğrencilerin matematik kaygısını azalttığı şeklinde yorumlanabilir. Zengin (2017), yazılımı kullanılarak tasarlanan öğretim sürecinin, öğretmen adaylarının matematik kaygısına etkisini incelediği çalışmada, GeoGebra yazılımıyla tasarlanan öğretim sürecinin, öğretmen adaylarının matematik kaygılarını azaltılmasına katkı sağladığı sonucuna ulaşmıştır. Bu bulgu, araştırmanın sonucunu desteklemektedir. Literatüre bakıldığında Furner ve Marinas (2016), Alday ve Panaligan (2013), Iossi'nin (2007) yaptıkları çalışmalarda araştırmanın sonucunu desteklemektedir. Araştırmada elde edilen bir diğer sonuç, deney grubundaki öğrencilerin öğretim teknolojilerine yönelik tutum ölçeğinden uygulama öncesinde ve sonrasında aldıkları puanlar arasında anlamlı bir fark olmadı̆̆ıdır. 
Araştırmada elde edilen bu sonuç Stols and Kriek (2011) in yaptıkları çalışmalarda elde ettikleri, GeoGebra' nın öğretim teknolojilerine yönelik tutumu olumlu etkilediği bulgusuyla örtüşmemektedir. Bu sonucun ortaya çıkmasında, tutum gibi duyuşsal özelliklerin değişmesi için daha uzun zamana ihtiyaç duyulmasından kaynaklandığı düşünülmektedir (Christensen, 2002). Öğrencilerin alışık olmadığı bir öğretim yöntemiyle ders işlemeye direnç gösterdiği ve tutumların da bu dirençten etkilendiği söylenebilir.

Karışık ölçümler için iki yönlü varyans analizi sonuçlarına göre, matematik başarı testinden alınan erişi puanları açısından deney grubu ve kontrol grubu arasında, deney grubu lehine anlamlı bir fark olduğu bulgusuna ulaşılmıştır. Bu bulgu Matematik dersinde GeoGebra dinamik yazılımı kullanımının, GeoGebra yazılımı desteksiz öğretimle karşılaştırıldığında öğrencilerin matematik başarısı üzerinde önemli bir etkiye sahip olduğu şeklinde yorumlanabilir. Literatüre bakıldığında, Williams, Charles-Ogan ve Adesope (2017), Kan (2014), Arbain ve Shukor(2014), Yahşi Sarı (2012), Filiz'in (2009) yaptıkları çalışmaların ulaştığı sonuçlar, araştırmanın bulgusuyla paralellik göstermektedir. Bu bağlamda, matematik derslerinde GeoGebra dinamik yazılımı kullanılmasının, öğrencilerin akademik başarılarını artırdığı söylenebilir (Saha, Ayub, ve Tarmizi, 2010; Tezer ve Deniz, 2009; Diković, 2009; Erbaş, 2005; Alakoç, 2003; Ersoy, 2003; Çağıltay, Çakıroğlu, Çağıltay ve Çakıroğlu, 2001). Araştırmada elde edilen bir diğer sonuç ise, matematik kaygı ölçeğinden alınan erişi puanları açısından deney grubu ve kontrol grubu arasında, anlamlı bir fark olmadığıdır. Bu sonuç matematik dersinde GeoGebra kullanılmasının, öğrencilerin matematik kaygısı üzerinde önemli bir etkisinin olmadığını göstermektedir. Bu durumunun kaygı gibi duyuşsal özelliklerin değiştirilmesi uzun zaman alan özellikler olmasından kaynaklandığı düşünülebilir. Duyuşsal bir özellik olan matematik kaygısının değiştirilememesi deneysel işlem sürecinin süresinden kaynaklandığı söylenebilir. Araştırmada elde edilen bir diğer sonuç, öğretim teknolojilerine yönelik tutum ölçeğinden alınan erişi puanları açısından deney grubu ve kontrol grubu arasında, kontrol grubu lehine anlamlı bir fark olduğudur. Tutum da kaygı gibi değiştirilmesi uzun zaman alan duyuşsal özelliklerdendir. Bu sonucun, öğrencilerin GeoGebra gibi bir öğretim teknolojisini derste kullanılmaya alışık olmadıkları için, öğrencilerin gösterdiği dirençten kaynaklandı̆̆ı düşünülebilir. Öğrencilere uygulama öncesi verilen GeoGebra tanıtım derslerinin süresinin daha uzun olmasının öğrencilerin gösterdiği direnci azaltacağı ve öğretim teknolojilerine yönelik tutumlarını olumlu yönde etkileyeceği düşünülmektedir.

Deney grubu öğrencilerinin GeoGebra dinamik yazılımına ilişkin görüşlerine dair kodlar incelendiğinde, öğrencilerin derste GeoGebra dinamik yazılımı kullanıımasının, matematiği eğlenceli hale getirdiğini, dikkat çektiğini, etkili öğrenme, öğrenmede kolaylık, kalıcı öğrenme, aktif öğrenme, görsellik, öğrenmede hız sağladığını ifade etmişlerdir. Bu sonucun, deney grubundaki öğrencilerin kontrol grubu öğrencileri ile karşılaştırıldığında matematik başarı testinden alınan son test puanlarının daha yüksek olmasına neden olduğu düşünülebilir. Etkili öğrenme, öğrenmede kolaylık, kalıı öğrenme, aktif öğrenme, görsellik, öğrenmede hız sağlama gibi bilişsel özelliklerinin akademik başarıyı artırdığı savına ulaşılabilir. Ayrıca, öğrenciler GeoGebra dinamik yazılımının en çok, eğlenceli, görsel, pratik, aktif, teknolojik bir araç olma, etkili öğrenme ve öğrenmede hız sağlama özelliklerini sevdiklerini vurgulamışlar ve GeoGebra dinamik yazılımını fizik ve kimya derslerinde de kullanmak istediklerini belirtmişlerdir.

\section{5.Öneriler}

Bu bölümde araştırmada elde edilen sonuçlar doğrultusunda uygulamaya ve araştırmacılara yönelik bazı öneriler sunulmuştur.

\section{Uygulamaya Yönelik Öneriler}

- GeoGebra dinamik yazılımının kullanılması öncesinde kapsamlı olarak GeoGebra yazılımı öğrencilere tanıtılmalı, programlı ilgili farklı etkinlikler yaptırılmalı ve öğrencilerin yazııımı incelemelerine olanak verilmelidir.

- Okullarda bulunan etkileşimli tahtalara GeoGebra yazılımı kurularak, temel seviyede de olsa öğrencilerin programla tanışması sağlanmalıdır.

- Öğrencilerin cep telefonlarına GeoGebra yazılımınının kurulması sağlanmalı böylece, öğrencilerin Ankara GeoGebra Enstitüsü'nü online olarak takip etmeleri ve interaktif bir öğrenme ortamında bulunmaları desteklenmelidir.

- Ortaöğretim matematik ders kitapları içerisinde bulunan GeoGebra ve benzeri yazılımlar destekli etkinlikler arttırılmalıdır. 


\section{Araştırmacılara Yönelik Öneriler}

- GeoGebra dinamik yazııımının, öğrencilerin tutum ve kaygı gibi duyuşsal özelliklerine etkisinin inceleneceği çalışmalarda, araştırma süresi uzatılabilir.

- GeoGebra dinamik yazılımının öğrencilerin duyuşsal özelliklerinden olan direnç, yılmazlık ve benzeri özellikleri üzerinde araştırmalar yapılabilir.

- Öğretmenlerin GeoGebra dinamik yazılımının kullanımı hakkındaki görüşleri ve önerileri araştırılabilir.

- Farklı dinamik yazılımların matematik başarısı üzerindeki etkisi incelenebilir.

\section{Kaynakça}

Abar, C., \& Barbosa, L. M. (2011). Computer algebra, virtual learning environment and meaningful learning: Is it possible?. Acta Didactica Napocensia, 4(1), 31-38.

Alakoç, Z. (2003). Matematik öğretiminde teknolojik modern öğretim yaklaşımları. The Turkish Online Journal Of Educational Technology, 2(1), 43-49.

Alday, R.B., \& Panaligan, A. B. (2013). Reducing math anxiety of ccs students through e-learning in analytic geometry. Educational Research International, 2(1), 76-90.

Arbain, N., \& Shukor, N. A. (2014). The effects of geogebra on students achievement. Procedia - Social And Behavioral Sciences, 172, 208-214.

Balcı, Şeker, H. (2014). Geogebra yazııımı ile geometri öğretiminin geometri ders başarısına ve geometri özyeterliliğine etkisi (Yayımlanmamış yüksek lisans tezi). Necmettin Erbakan Üniversitesi, Konya.

Baloğlu, M. (2001). Matematik korkusunu yenmek. Kuram Ve Uygulamada Eğitim Bilimleri Dergisi. 1(1), 5976.

Boz, N. (2008). Matematik neden zor?. Necatibey Eğitim Fakültesi Elektronik Fen ve Matematik Eğitimi

Dergisi (EFMED), 2(2), 52-65.

Can, A. (2017). SPSS ile nicel veri analizi (5.baskı). Ankara: PegemA Yayınclık.

Chrysanthou, I. (2008). The use of ICT in primary mathematics in Cyprus: The case of geogebra (Unpublished) master's thesis), University of Cambridge, UK.

Choi, K. (2010). Motivating students in learning mathematics with geogebra. Annals Computer Science Series, 8(2), 65-76.

Christensen, R. R. (2002). Effects of technology integration education on the attitudes of teachers and students, Journal of Research on Technology in Education, 34(4), 411-433.

Çağıltay,K., Çakıroğlu, J., Çağıltay, N., \& Çakıroğlu, E. (2001). Öğretimde bilgisayar kullanımına ilişkinöğretmen görüşleri. Hacettepe Üniversitesi Eğitim Fakültesi Dergisi, 21, 19-28.

Çetin, E., Erdoğan, A., \& Yazlık, D. Ö. (2015). Geogebra ile öğretimin sekizinci sınıf öğrencilerinin dönüşüm geometrisi konusundaki başarılarına etkisi, Uluslararası Türk Eğitim Bilimleri Dergisi, 4, 84-92.

Dijanic, Z. B. (2011, March). Discovery learning in mathematics by using dynamic geometry software geogebra action research, Proceeding of The 3rd International Scientific Colloquium, Mathematics and Children. Strossmayer University, Osijek.

Dikovic, L. (2009). Applications geogebra into teaching some topics of mathematics at the college level, ComSIS, 6(2), 191-203.

Dursun, Ş., \& Dede, Y. (2004). Öğrencilerin matematikte başarısını etkileyen faktörler: Matematik öğretmenlerinin görüşleri bakımından, Gazi Eğitim Fakültesi Dergisi, 24(2), 217-230. 
Escuder, A., \& Furner, J. M. (2012, March). Impact of geogebra in math teacher's professional development. Proceeding of Twenty-third Annual International Conference on Technology in Collegiate Mathematics, Denver.

Erbaş, A. K. (2005). Çoklu gösterimlerle problem çözme ve teknolojinin rolü. TOJET: The Turkish Online Journal Of Educational Technology, 4(4), 88-92.

Ersoy, Y. (2003). Teknoloji destekli matematik eğitimi-1: Gelişmeler, politikalar ve stratejiler. İlköğretim-Online, 2(1), 18-27.

Filiz, M. (2009). GeoGebra ve Cabri Geometri II dinamik geometri yazılımlarının web destekli ortamlarda kullanılmasının öğrenci başarısına etkisi (Yayımlanmamış yüksek lisans tezi). Karadeniz Teknik Üniversitesi, Trabzon.

Furner, J. M., \& Marinas, C .A. (2016). Mathematics anxiety in society: A real phenomena and a real solution, Transformations,1(1), 24-36.

Hähkiöniemi, M., \& Leppäaho, H. (2011). Prospective mathematics teachers' ways of guiding high school students in geogebra-supported inquiry tasks. International Journal for Technology in Mathematics Education, 19(2), 4557.

Iossi, L. (2007, April). Strategies for reducing math anxiety in post-secondary students, Proceeding of the Sixth Annual College of Education Research Conference: Urban and International Education Section, Miami.

Kaleli Yılmaz, G., Ertem, E., \& Güven, B. (2010). Dinamik geometri yazııımı cabri'nin 11.sınıf öğrencilerinin trigonometri konusundaki öğrenmelerine etkisi, Turkish Journal of Computer and Mathematics Education, $1(2), 200-216$.

Kan, O. (2014). Geogebra destekli öğretimin lineer cebir dersine ait bazı konularda akademik başarı üzerine etkisi(Yayımlanmamış yüksek lisans tezi). Selçuk Üniversitesi Eğitim Bilimleri Enstitüsü, Konya.

Karaarslan, E., Boz, B., \& Yıldırım, K. (2013, Ekim). Matematik ve geometri eğitiminde teknoloji tabanlı yaklaşımlar. 18. Türkiye'de İnternet Konferansında sunulmuş bildiri. İstanbul Üniversitesi, İstanbul.

Karasar, N. (2015). Bilimsel araştırma yöntemi (28. Baskı). Ankara: Nobel.

Karsavuran, S. (2014). Sağlık sektöründe tükenmişlik: Ankara'daki sağlık bakanlığı hastaneleri yöneticilerinin tükenmişlik düzeyleri, H.Ü. İktisadi Ve İdari Bilimler Fakültesi Dergisi, 32(2), 133-163.

Kepçeoğlu, í. (2010). GeoGebra yazılımıyla limit ve süreklilik öğretiminin öğretmen adaylarının başarısına ve kavramsal öğrenmelerine etkisi (Yayımlanmamış yüksek lisans tezi). Marmara Üniversitesi Eğitim Bilimleri Enstitüsü, İstanbul.

Khalil, M., Faroo, R. A, Çakıroğlu, E., Khalil, U., \& Khan, D. M. (2018). The development of mathematical achievement in analytic geometry of grade-12 students through geogebra activities, Eurasıa Journal Of Mathematics, Science And Technology Education, 14(4), 1453-1463.

Kllogjeri, P. (2015). GeoGebra in teaching and learning mathematics in Albanian secondary schools, (Unpublished doctorate thesis). The University of Debrecen, Hungary.

Lopez, N. R. (2011). Geogebra workshop for the initial teacher training in primary education. International Journal For Technology In Mathematics Education, 18(4), 183-188.

Majerek, D. (2014). Application of geogebra for teaching mathematics. Advances In Science And Technology Research Journal, 8(24), 51-54.

Martinez, A. R. (2015). The effects of using geogebra on student achievement in secondary mathematics, (Unpublished master's theses). California State University, Monterey Bay.

Ortaöğretim Matematik Dersi Öğretim Programı (2018). Milli Eğitim Bakanlığı Talim ve Terbiye Kurulu Başkanlığı, Ankara. 
Mercan, M. (2012). Illköğretim 7. Sınıf matematik dersine ait "Dönüşüm Geometrisi" alt öğrenme alanının öğretiminde, dinamik geometri yazılımı GeoGebra'nın kullanımının öğrenci başarısı ve kalıcılık üzerindeki etkisi (Yayımlanmamış yüksek lisans tezi). Gazi Üniversitesi Eğitim Bilimleri Enstitüsü, Ankara.

Metin, M., Kaleli Yılmaz, G., Coşkun, K., \& Birişçi, S. (2011) Developing an attitude scale towards using instructional technologies for pre-service teachers. Turkish Online Journal Of Educational Technology, 11 (1), 36-45.

Miles, B. M., \& Huberman M. A. (2016). Nitel veri analizi, (çev. S. Akbaba Altun ve A. Ersoy). Ankara: Pegem Akademi.

Moss, L. J. (2000). The use of dynamic geometry software as a cognitive tool (Unpublished doctorate thesis). The University of Texas, Austin.

Mukurı, M. I. (2016). Feasibility of using geogebra in the teaching and learning of geometry concepts in secondary schools in Kajiado County, Kenya (Unpublished doctorate thesis). Kenyatta University, Kenya.

Öz, M. (2015). Ortaokul 7. Sınıf matematik dersi "Geometrik Cisimler" alt öğrenme alanının öğretiminde dinamik matematik yazılımı GeoGebra 5.0 kullanımının öğrenci başarısına etkisi (Yayımlanmamış yüksek lisans tezi). Gazi Üniversitesi Eğitim Bilimleri Enstitüsü, Ankara.

Özçakır Sümen, Ö. (2013). Geogebra yazııımı ile simetri konusunun öğretiminin matematik başarısına ve kaygısına etkisi (Yayımlanmamış yüksek lisans tezi). Ondokuz Mayıs Üniversitesi Eğitim Bilimleri Enstitüsü, Samsun.

Richardson, F.C., \& Suinn, R.M. (1972). The mathematics anxiety rating scale: Psychometric data. Journal Of Counseling Psychology, 19, 551-554.

Sarıtaş, M. (Ed.). (2013). Öğretim teknolojileri ve materyal tasarımı. Ankara: PegemA.

Saha, R. A., Ayub, A. F. M., \& Tarmizi, R. A. (2010). The effect of geogebra on mathematics achievement: enlightening coordinate geometry learning. Procedia Social And Behavioral Sciences, 8, 686-693.

Stols, G., Kriek, J. (2011). Why don't all maths teachers use dynamic geometry software in their classrooms?. Australasian Journal Of Educational Technology, 27(1), 137-151.

Thambi, N., \& Kwan, Eu, L. (2013). Effect of students' achievement in fractions using geogebra. SAINSAB, 16, 97-106.

Taş, S. (2016). Geometrik cisimler konusunun öğretiminde Geogebra kullanımının akademik başarıya etkisi (Yayımlanmamış yüksek lisans tezi). Gazi Üniversitesi, Eğitim Bilimleri Enstitüsü, Ankara.

Tataroğlu, B. (2009). Matematik öğretiminde akıllı tahta kullanımının 10. sınıf öğrencilerinin akademik başarıları, matematik dersine karşı tutumları ve öz-yeterlik düzeylerine etkileri (Yayımlanmamış yüksek lisans tezi). Dokuz Eylül Üniversitesi Eğitim Bilimleri Enstitüsü, İzmir.

Tezer, M., \& Deniz, A. K. (2009, Mayıs). Matematik dersinde interaktif tahta kullanarak yapılan denklem çözümünün öğrenme üzerindeki etkisi. Dokuzuncu Uluslararası Eğitim Teknolojileri Konferasında sunulmuş bildiri, Hacettepe Üniversitesi, Ankara.

Trujillo, K., \& Hadfield, O. (1999). Tracing the roots of mathematics anxiety through in-depth interviews with preservice elementary teachers. College Student Journal, 33(2), 219-233.

Vasquez, D. E. (2015). Enhancing student achivement using geogebra in a technology rich environment, (Unpublished doctorate thesis). Faculty of California State Polytechnic University, Pomona.

Williams, C., Charles-Ogan, G., \& Adesope, R. Y. (2017). The geogebra interactıve software and senıor secondar school three (sss3) students' Interest and achievement in mathematıcs. International Journal Of Mathematics And Statistics Studies, 5(1), 1-8.

Woodard, T. (2004). The effects of math anxiety on post-secondary developmental students as related to achievement, gender and age. Inquiry, 9(1), 1-5.

Yahşi Sarı, H. (2012). ilköğretim 7.sınıf matematik dersi "Dönüşüm Geometrisi "alt öğrenme alanının öğretiminde dinamik geometri yazılımlarından Sketchpad ile Geogebra'nın kullanımlarının öğrencilerin başarısına ve öğrenmelerin kalıcılığına etkilerinin karşılaştııılması (Yayımlanmamış yüksek lisans tezi). Gazi Üniversitesi Eğitim Bilimleri Enstitüsü, Ankara. 
Yenilmez K., \& Dereli A. (2009). Ilköğretim okullarında matematiğe karşı olumsuz önyargı oluşturan etkenler. EJournal Of New World Sciences Academy. 4(1), 25-33.

Yenilmez, K., \& Özbey, N. (2006). Özel okul ve devlet okulu öğrencilerinin matematik kaygı düzeyleri üzerine bir araştırma, Uludağ Üniversitesi Eğitim Fakültesi Dergisi, 19(2), 431-448.

Zengin, Y. (2017). Geogebra yazııımının matematik kaygısı ve matematik öğretme kaygısına etkisinin İncelenmesi. Yüzüncü Yıl Eğitim Fakültesi Dergisi, 14(1), 908-939.

Žilinskienè, I. (2014, November). Use of GeoGebra in primary math education:A theoretical approach, Proceedings of the Lithuanian Mathematical Society, Vilnius University, Lithuania. 